\title{
The chicken limb deformity gene encodes nuclear proteins expressed in specific cell types during morphogenesis
}

\author{
Andreas Trumpp, Patricia A. Blundell, José Luis de la Pompa, and Rolf Zeller ${ }^{1}$ \\ EMBL Differentiation Programme, 6900 Heidelberg, Germany
}

\begin{abstract}
The chicken limb deformity (ld) mutation affects morphogenesis of both limbs and kidneys and is one of few murine mutations for which the affected gene has been isolated. Analysis of the chicken homolog reveals evolutionary conservation of large parts of the encoded $1 d$ gene products. This is the first study of these proteins, their intracellular localization, and their temporal and spatial distribution during embryogenesis. A major 180-kD protein is expressed in chicken embryos and certain adult tissues. The proteins are localized in the nuclei of different embryonic cell types in a characteristic punctate pattern. In the developing chicken limb bud, they are expressed in the newly differentiated apical ectodermal ridge and the mesenchymal compartment, where an unequal distribution along the anteroposterior and, subsequently, the dorsoventral axes, is observed. During kidney morphogenesis, expression is initially restricted to the epithelial compartment of the pronephros and mesonephros. These results correlate well with the previous analysis of the murine $1 d$ phenotype and imply determinative roles for $l d$ gene products during the morphogenesis of limbs and kidneys. Unexpected expression in the notochord, floor plate, and ventral horns suggests an involvement of the $I d$ gene products in establishment of the dorsoventral polarity of the neural tube.
\end{abstract}

[Key Words: Chicken limb deformity (Id) gene; nuclear proteins; limb development; kidney development; dorsoventral neural tube polarity]

Received September 26, 1991; revised version accepted October 24, 1991.

A major task of developmental biology is to unravel the molecular networks that control morphogenesis and differentiation in embryos. The combination of classic developmental genetics and molecular biology has proven very powerful and allowed the isolation and analysis of many developmentally important genes in invertebrates during the past years. Several morphogenetic mutations have been described for the mouse /Lyon and Searle 1989|, but only a few of the affected genes have been isolated so far (e.g., Balling et al. 1988; Herrmann et al. 1990; Woychik et al. 1990a); therefore, the molecular mechanisms regulating vertebrate pattern formation remain largely unknown.

Numerous mutations affecting limb development have been described (Grueneberg 1963), but isolation of some of the affected loci has only recently become feasible through insertional mutagenesis in transgenic mice [limb deformity (Woychik et al. 1985); limbless (McNeish et al. 1988); extra toes (Pohl et al. 1990)]. For the recessive mouse limb mutation, limb deformity $(1 d)$, the affected gene has been identified (Woychik et al. 1985, 1990a; Maas et al. 1990) and its transcription has been analyzed in some detail. The $l d$ gene was shown to be transcribed as a complex array of alternatively spliced

${ }^{1}$ Corresponding author.
mRNAs both in embryos and certain adult tissues. Owing to alternative splicing within the identified open reading frames (ORFs), it was postulated that this gene could encode several related gene products [formins (Woychik et al. 1990a; Jackson-Grusby et al., this issue)], which could have distinct functions during murine embryogenesis and in adult tissues. This molecular analysis did not, however, provide any evidence for the expression pattern, intracellular localization, or possible functions of the $1 d$ gene products.

Five independent recessive murine $1 d$ alleles have been isolated and show a pleiotropic phenotype affecting limbs and kidneys. Varying degrees of uni- or bilateral renal aplasia are seen in all five alleles, suggesting a defect in kidney morphogenesis (Kleinebrecht et al. 1982; Messing et al. 1990; Woychik et al. 1990b; R.L. Maas, R. Zeller, and P. Leder, unpubl.). Analysis of the mutant limb phenotype reveals specific truncations of the anteroposterior axis for all $1 d$ alleles (Woychik et al. 1985, 1990b; Messing et al. 1990). During early limb-bud formation, a significant shortening of the anteroposterior limb axis and a lack of complete apical ectodermal ridge (AER) differentiation occur. These alterations suggest a direct involvement of the $1 d$ gene in the early determinative events that establish the primary limb pattern (Zeller et al. 1989). 
Establishment of the anteroposterior axis in the developing limb is one of the best studied pattern-forming processes in vertebrates. Classic experiments have shown that two morphogenetically active regions, the zone of polarizing activity (ZPA) and the AER, are involved in determining positional information for both the anteroposterior and proximodistal limb axes (for review, see Fallon et al. 1983; Tickle 1991). The ZPA consists of mesenchymal cells located at the posterior margin of the limb bud and acts as a signaling region to specify the anteroposterior pattern. Wolpert (1969) suggested that the initial polarity is established by a morphogen, which could be retinoic acid (for review, see Tickle 1991) or a close relative (Thaller and Eichele 1990). Grafting experiments on the developing chicken limb bud (for review, see Tickle 1980) have shown that embryonic structures other than the ZPA also produce this morphogenetic activity. The mesonephros (Saunders 1977), Hensen's node, notochord (Hornbruch and Wolpert 1986), and floor plate (Wagner et al. 1990) are among such structures. Recently, Yamada et al. (1991) have proposed that dorsoventral patterning of the neural tube by the notochord and the floor plate is controlled by a mechanism similar to that determining the anteroposterior axis in the limb. These experiments suggest a common molecular basis for the morphogenetic activity that determines positional information in these different structures (Wagner et al. 1990). Members of different gene families, such as retinoic acid receptors, peptide growth factors and their receptors, and homeo box-containing genes are candidate molecules for mediating morphogenesis in the developing limb and other embryonic structures (for review, see Eichele 1990; Duboule 1991).

The chicken embryo is the classic experimental system used to analyze limb pattern formation (for review, see Eichele 1990). Evolutionary conservation of the mechanisms controlling vertebrate limb pattern formation (for review, see Tickle 1980) and of the $1 d$ gene (Woychik et al. 1990a) prompted us to isolate the chicken homolog. We raised specific polyclonal antisera that revealed the $l d$ gene products to be nuclear; the temporal and spatial expression patterns during chicken embryogenesis were studied by immunohistochemistry. Unequal distribution of the $l d$ gene products in limb buds during formation of the primary axes and expression in the epithelial compartment of the developing kidneys indicates an involvement in the morphogenetic processes governing pattern formation.

\section{Results}

Isolation of a chicken embryonic ld transcript reveals evolutionary conservation of the encoded gene products

A genomic chicken $l d$ probe (Woychik et al. 1990a) containing a conserved exon shown to be expressed in chicken embryos (Fig. 1A, underlined peptide sequence; Blundell et al. 1992) was initially used to screen cDNA libraries in an attempt to isolate the $1 d$ transcripts relevant to limb and kidney morphogenesis. The cDNA libraries were constructed from chicken embryos of stages 19-23 (Hamburger and Hamilton 1951), and several strongly hybridizing clones were isolated. To extend the chicken $1 d$ cDNA sequences, the libraries were screened repeatedly by using the most $5^{\prime}$ sequences as probes. Nineteen partially overlapping cDNA clones spanning $4.7 \mathrm{~kb}$ were used to derive the composite mRNA shown in Figure 1B. Sequence analysis reveals a 1213-aminoacid ORF encoding a putative protein with a predicted molecular mass of $135 \mathrm{kD}$ (Fig. 1A). The ATG codon chosen as the likely translational start site matches perfectly the initiation consensus sequence proposed by Kozak (1987); and $5^{\prime}$ to its position, several stop codons are present in all three possible reading frames (data not shown). Five independent cDNA clones containing the 5 ' part of the composite mRNA confirm the ATG and the upstream stop codons.

Comparison of this chicken embryonic ld ORF with the previously isolated murine adult $I d$ ORF (Woychik et al. 1990a) reveals strong evolutionary conservation of the carboxy-terminal ( $81 \%$ amino acid identity) and central $(61 \%)$ domains (Fig. 1B). The disruption of the ld gene in the $l d^{H d}$ (Maas et al. 1990) and $l d^{I n 2}$ (Woychik et al. 1990b) alleles occurs within the highly conserved carboxy-terminal domain (Fig. 1B). A proline-rich region that is less conserved (55\%, Fig. 1, dashed box) has no particular secondary structure, which suggests that it may serve as a molecular hinge (Woychik et al. 1990a; B. Altenberg and C. Sander, pers. comm.) separating the carboxy-from the central domain. The amino-terminal domain (463 amino acids) of the chicken embryonic ORF does not show any homology to the previously isolated murine $1 d$ ORF (data not shown). The divergence point between the two species (arrowhead, Fig. 1) matches one of the sites of alternative splicing discovered from analysis of the murine ld gene (Woychik et al. 1990a). Secondary structure analysis suggests that a small unstructured hinge region spanning this divergence point (positions 450-490; B. Altenberg and C. Sander, pers. comm.) separates the amino-terminal from the central domain.

Recently, Jackson-Grusby et al. (this issue) have isolated a variant murine $l d$ transcript expressed in limb buds of mouse embryos (gestational day 11). The aminoterminal domain (457 amino acids) of this murine $1 d$ ORF shows $39 \%$ overall identity to the chicken embryonic Id ORF (Fig. 1B). Within these amino-terminal domains, several stretches of 20-50 amino acids with much higher homology $(70-80 \%$ ) are present (data not shown). These data, together with the conserved acidity of both domains (pI 4.5), suggest that the transcripts encode the homologous $1 d$ gene products of the two species. So far, both the mouse and chicken $1 d$ ORFs show no significant homologies to other known proteins.

\section{Molecular analysis of the chicken ld gene products during embryogenesis and in adult tissues}

To analyze expression of the chicken $l d$ gene at the 
Figure 1. Primary amino acid sequence of a chicken embryonic ld gene product deduced from sequencing overlapping cDNA clones. $(A)$ Deduced amino acid sequence. The portion of the ORF boxed with stippled lines (positions 412-614) corresponds to fusion protein FP2; that boxed with solid lines (positions 963-1213), to fusion protein FP1. Amino acids 652-751, boxed with dashed lines, indicate the proline-rich hinge region. The underlined amino acids (positions 1122-1170) are encoded by the chicken genomic exon (Woychik et al. 1990a; Blundell et al. 1992) that was initially used to screen the cDNA libraries. $(B)$ Scheme of the cloned ld transcript. The thin regions flanking the ORF (AUG to UGA) correspond to the cloned parts of the $5^{\prime}$ and $3^{\prime}$-flanking regions. The DNA probes used for molecular analysis (probes $1-3$ ) are shown. FP1 and FP2 represent the two fusion proteins. The hatched regions of the ORF indicate the two evolutionarily highest conserved domains; the solid box represents the proline-rich hinge region; the open region represents the amino-terminal domain. Numbers indicate the percentage of evolutionary conservation between the isolated $\mathrm{mu}$ rine (bottom line) (Woychik et al. 1990a; Jackson-Grusby et al., this issue) and chicken Id ORFs. The disruptions of the murine $l d$ gene by both the $1 d^{H D}$ (Maas et al. 1990) and $l d^{\text {In2 }}$ (Woychik et al. 1990b/ mutations are indicated. Arrowheads in $A$ and $B$ mark the divergence point of the chicken and mouse (JacksonGrusby et al., this issue) embryonic $1 d$ cDNAs from the murine ld sequences published previously (Woychik et al. 1990a).

mRNA level and to identify the encoded gene products, specific cDNA probes (Fig. 1B) and a polyclonal antiserum raised against part of the highly conserved carboxyterminal domain (Fig. 1, FPl; for details, see Materials and methods) were used. The FP1 domain was chosen because the expression of $l d$ transcripts containing this domain is disrupted in both $1 d^{H d}$ and $l d^{I n 2}$ mutant mice (Maas et al. 1990). The FP1 antiserum therefore permits analysis of the $1 d$ gene products relevant for limb and kidney morphogenesis, as these are disrupted by the murine $1 d$ mutations. In addition, a polyclonal antiserum
A

1 MEGGNAGCSR QLPERAGPAE SEPDVFTTFA VRTLLGLTTK LESVTPKEEE

51 AVLKAFQPLH IDVNTQANNR YERNDNDGVD DSENQHCESC TSDQADPMSG

101 SRAEPELEPE PAGQNEILLP HLRSVQTSLS ESDNDAILVQ GTLVHTTSDT

151 ESDGESKDPD ADETGTSKCG LNNAALSAVA LDGNNQSKEE SDSEGYGHSD

201 DTVGRDDTEL HPPISQWLPR KLDSILEHDS SGKDRTLMDE QFSCLLATGE

251 CSPELSGEDQ RPSADNVSFH KAALTERSFQ LPAFFSGLRV RKKGLNTEDG

301 ETITEIKPRE NDLALLKLRQ PVKKSNITSG LTTKKKSSEP KASPTFLEQL

351 SHLLNIDVSK NDERTQDSGA GFGETEDSDE GPENKASGQT EPLFPSEEIK

401 SSPAESALDV EูKALTRPPK KETTADPSEL EAIKRKMRNE KESLKAVFER 451 SKSKPGDGPS DKSPDLSPSE ODDKTPGRLQ TVWPPPKANH EEVKVGLKYT

501 EAEYQAAILH LKREHKEEIE TLKSQFELRV FHIRGEHAVS TAQLEETIAH

551 LKNELDNKLN RRNEEARDIG VSTEDDNLPK TYRNVCIQTD RETFIKPSEE

601 ENRAVKNNQI VPKK FNISSI THSISTQGEN KDSYDVPSSE SVLSCQPKQM

651 LPPSPPPPPP PPPPPPPPPP PFSDSSLPGL VPPPPPLPTG PTSVTPHFAE:

701 GPPLPPQLSE GCRDFQAPAP PAPPPLPGLG PPVPPPLPGS GLPPPPPPPG

751 EGLLFNSTLS SSQGPRKPAI EPSRPMKPLY WTRIQLQGSR KTAIPTLWES

801 LEEPDILDTT EFEYLFSKDT TQEKRKPLSE TYEKKTKAKK IIKLLDGKRS

851 QTVGILISSL HLEMKDIQQA ILCVDDSVVD LETLEGLYEN RAQKDELEKI

901 EQYYQTSKEE ELKLLDKPEQ FLYELSQIPN FTERAQCIIF QSVFSEGITS

951 VHRKVDIITR VS KALLNMTS VKEILGLILA FGNYMNGGNR TRGQADGFGL

1001 EILPKLKDVK SRDNRINLVD YVVIYYLRHC DKEAGTDKSI FPLPEPQDFF

1051

1101

1151

1201 QASQVKFEDL IKDLRKLKRD LEASEKQMKL VCRESSEEHL QPFKEKLEEF FQKAKEERKK EESSLENAQK CFEETVGYFG IKPKPGEKEI TPNYYFTUWY

EFCSDFKTIW KRESKSISKE RIKVAQQSVS KLTAEKKVET KKINPTASLK

ERLRQKEANV NAN*

B

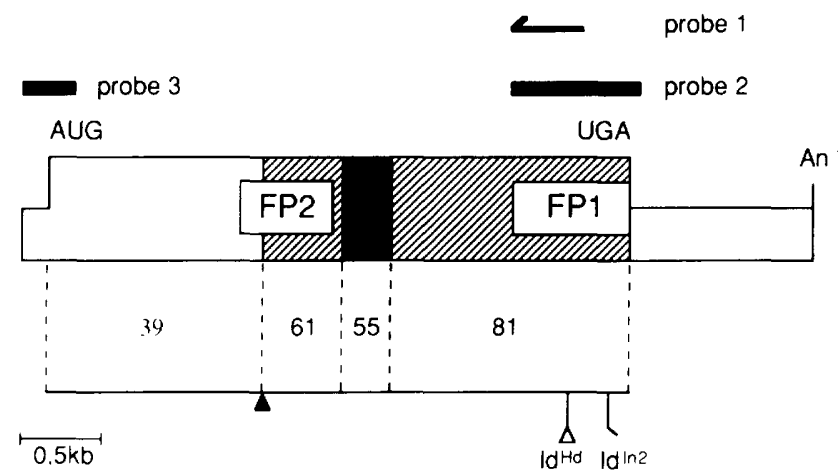

was raised against the FP2 domain (Fig. 1) to confirm the results obtained using the FP1 antiserum.

Adult chickens express $1 d$ transcripts (analyzed by RNase protection; Fig. 2A) and proteins in certain tissues (using Western blot analysis; Fig. 2B) in a pattern similar to that reported for the mouse (Woychik et al. 1990a; Jackson-Grusby et al., this issue). The $l d$ gene is expressed in brain, kidney (Fig. 2A,B), heart, and intestine (data not shown), whereas little or no expression is seen in bursa (data not shown) and liver (Fig. 2A,B). A major $180-\mathrm{kD}$ protein is detected using affinity-purified FP1 an- 
A
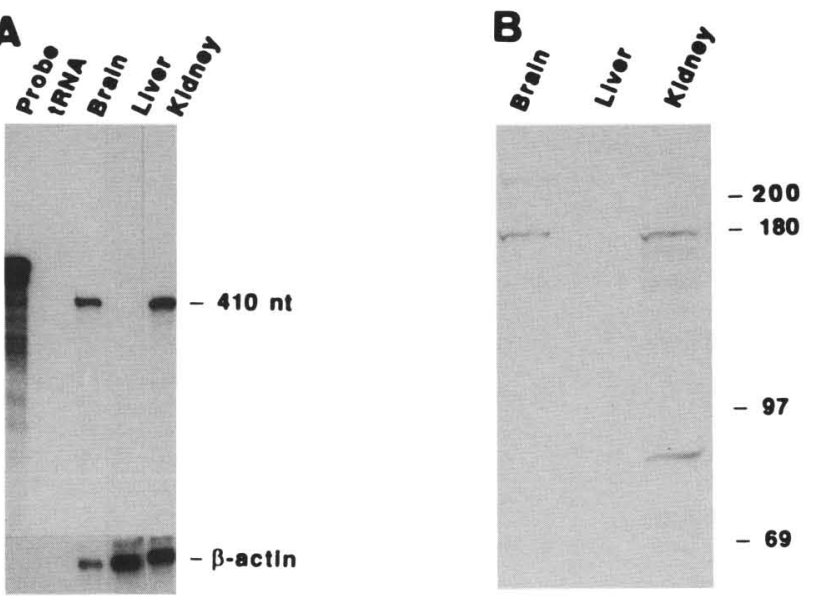

C

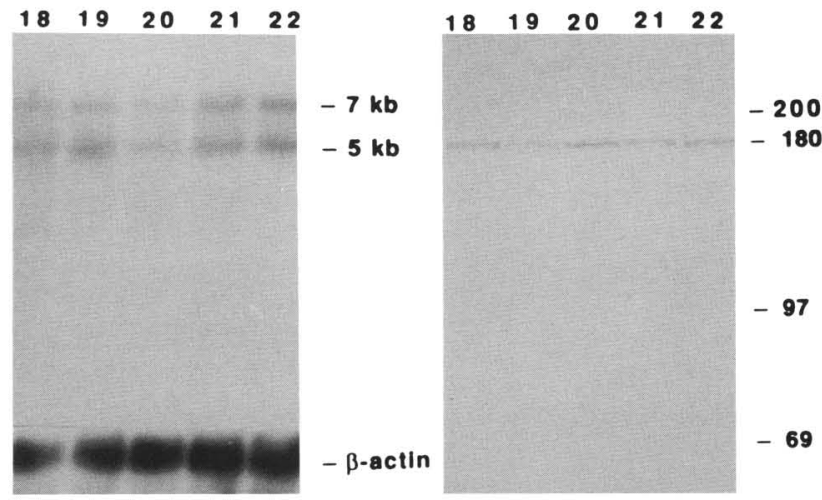

E

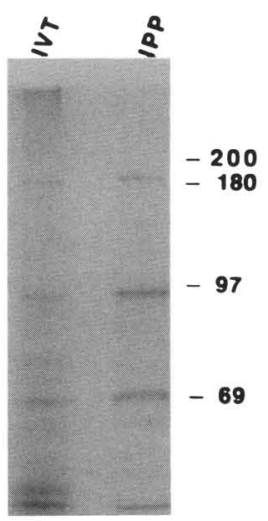

tiserum (Fig. 2B). The additional polypeptides seen probably correspond to tissue-specific isoforms (postulated by Woychik et al. 1990a; Jackson-Grusby et al., this issue) or degradation products. When affinity-purified FP2 antiserum is used for analysis the same major protein bands are detected (data not shown), indicating specific detection of the $1 d$ gene products by both antisera. In all tissues (and cell lines; data not shown) there is a strict
Figure 2. The chicken $l d$ gene encodes a major $180-\mathrm{kD}$ protein expressed during embryogenesis and in certain adult tissues. $|A|$ Analysis of $l d$ transcription in adult tissues by RNase protection using $\left[{ }^{32} \mathrm{P}\right]$-labeled anti-sense probe 1 (Fig. 1B). Thirty micrograms of total RNA (normalized for poly $(\mathrm{A})^{+}$content) was used for each tissue ( 3 days of exposure). Two micrograms of total RNA was analyzed using a $\beta$-actin probe as a control $(15-\mathrm{hr}$ exposure). (Probe) Anti-sense probe 1 (see Fig. 1B; also contains linker sequences at its $3^{\prime}$ end); (tRNA) control to reveal nonspecifically protected bands; $(410 \mathrm{nt})$ specific full-length protection of a 410-nucleotide fragment. (B) Analysis of $1 d$ protein distribution in adult tissues using affinity-purified FP1 antibodies. About $50 \mu \mathrm{g}$ of protein per tissue (normalized) is run on a $7.5 \% 30: 1$ SDS-polyacrylamide gel and immunoblotted. Note that a major $180-\mathrm{kD}$ protein is expressed in brain and kidney, whereas neither RNA (see $A$ ) nor protein are present in liver, revealing specificity of the FPl antiserum. Numbers indicate sizes of protein markers in $\mathrm{kD}$. (C) Northern analysis of $1 d$ gene expression during embryogenesis. Poly $(\mathrm{A})^{+}$RNA is prepared from $500 \mu \mathrm{g}$ of total RNA from chicken embryonic stages 18-22 and transferred from a $1 \%$ denaturing agarose gel. The filter is exposed for 5 days after hybridization to ${ }^{32} \mathrm{P}$-labeled probe 2 (see Fig. 1B). Approximate sizes of the 5- and 7-kb transcripts are calculated using RNA markers. To check RNA integrity, the filter is rehybridized to a $\beta$-actin probe (15-hr exposure). (D) $l d$ protein distribution in stages 18-22 chicken embryos. About 50 $\mu \mathrm{g}$ of protein (normalized) per stage is separated on a $7.5 \% 30: 1$ SDS-polyacrylamide gel and immunoblotted using affinity-purified FPl antibodies. Note that only a $180-\mathrm{kD}$ band is seen in all stages analyzed. Numbers indicate sizes of protein markers in $\mathrm{kD}$. $(E)$ In vitro transcription and translation of the cloned $l d$ ORF. (IVT) In vitro translation of the composite $1 d$ cDNA using $\left[{ }^{35} \mathrm{~S}\right]$ methionine to label the products. (IPP) Immunoprecipitation of the in vitro-translated peptides using FP1 antiserum (for details, see Materials and methods). Equal amounts of in vitrotranslated products are used for either immunoprecipitation or direct electrophoresis on a $7.5 \% 30: 1$ SDS-polyacrylamide gel. Note the $180-\mathrm{kD}$ translation product. Numbers indicate sizes of protein markers in $\mathrm{kD}$.

correlation between $1 d$ mRNA levels (Fig. 2A) and the amounts of protein seen using either affinity-purified FP1 (Fig. 2B) or FP2 antibodies (data not shown). This correlation suggests no major regulation of protein levels by post-transcriptional control.

Northern analysis of poly $(\mathrm{A})^{+}$RNA isolated from different embryonic stages (Fig. 2C) using probe 2 (Fig. 1B) reveals $l d$ transcripts of $\sim 5$ and $7 \mathrm{~kb}$ in stages $15-25$ 
(only stages 18-22 are shown in Fig. 2C). Probes derived from different regions of the $4.7-\mathrm{kb}$ composite cDNA (Fig. 1B) all detect both transcripts (data not shown) with the exception of the most $5^{\prime}$ probe (Fig. 1B, probe 3). This probe no longer detects the $7-\mathrm{kb} l d$ transcript, which suggests the existence of an as yet unidentified alternative 5' end for this transcript (data not shown). Most importantly, these results provide compelling evidence that the 4.7-kb composite cDNA (Fig. 1) corresponds to the $5-\mathrm{kb}$ embryonic $1 d$ transcript (Fig. $2 \mathrm{C}$ ). Western blot analysis of embryonic extracts using affinity-purified FP1 (Fig. 2D) and FP2 (data not shown) antibodies reveals the expression of a major $180-\mathrm{kD}$ protein in stages $15-25$ (only stages 18-22 are shown in Fig. 2D). From cDNA cloning (Fig. 1) and Northern blot analysis (Fig. 2C), the data suggest that the $5-\mathrm{kb}$ embryonic $I d$ transcript encodes a protein with an apparent molecular mass of 180 $\mathrm{kD}$. Because only a $180-\mathrm{kD}$ protein has been detected in embryos (Fig. 2D), the 7-kb $1 d$ transcript (with an alternative 5 ' end; see above) probably encodes either a gene product with the same apparent molecular mass or a minor species not yet detected.

The predicted molecular mass of the protein encoded by the cloned embryonic ORF (Fig. 1A) is, however, only $135 \mathrm{kD}$, which is smaller than the apparent molecular mass of the major $1 d$ protein seen in embryonic extracts (Fig. 2D). To resolve this discrepancy, the embryonic ld ORF was assembled in-frame from three overlapping cDNA clones and translated using an in vitro transcription and translation system (Fig. 2E). Analysis of the translation products revealed several bands, the largest of which is $180 \mathrm{kD}$, corresponding in size to the major protein seen by Western analysis of tissues and embryos. This protein and several shorter polypeptides were specifically immunoprecipitated using the FP1 antiserum (Fig. 2E), whereas no proteins were precipitated with preimmune serum (data not shown). The difference between the predicted $(135 \mathrm{kD})$ and apparent $(180 \mathrm{kD})$ molecular mass is caused either by abnormal migration, per- haps owing to the proline-rich region (Fig. 1A), or to posttranslational modification of the protein (J.L. de la Pompa, T. Papavassiliou, and R. Zeller, unpubl.). These data show that the cloned 5-kb embryonic $1 d$ transcript encodes a protein with an apparent molecular mass of $180 \mathrm{kD}$ and that this corresponds in size to the major species detected in chicken embryos and adult tissues.

\section{The ld gene encodes nuclear proteins}

To determine the subcellular localization, cultured embryonic cells expressing the $l d$ gene were used for immunofluorescence studies. The FP1 antiserum /affinity purified or crude; see Materials and methods) reveals nuclear localization of the antigen. The characteristic punctate distribution seen in the nuclei of primary chicken embryonic fibroblasts (Fig. 3A) is representative of the different cell types analyzed. Most cells also show varying levels of diffuse nucleoplasmic staining. During mitosis, the antigen disperses in the cytoplasm and no particular association with chromosomes is seen (Fig. $3 \mathrm{~A}$, arrowhead).

The FP1 antiserum has also been used to study the temporal and spatial distribution patterns of the $1 d$ gene products during embryonic development using histological sections of chicken embryos (see Figs. 3-7). Cell nuclei of embryos expressing the FP1 antigen appear either black or brown, owing to complexing of the secondary antibody with horseradish peroxidase. In contrast, nuclei of nonexpressing cells appear as bright spots, owing to counterstaining with Hoechst 33258 (for details, see Materials and methods). Expression of the $1 d$ protein in embryos (Fig. 3B) is not limited to cells of the developing limb buds (Figs. 3B and 7) and kidneys (Figs. 3B, 4, and 5), as might have been expected from analysis of the murine ld phenotype. Proteins are also detected in the developing notochord and neural tube (Figs. 4 and 6), brain (data not shown), myotome (Figs. 3B and 4), heart (data not shown), and epithelial lining of the gut (Fig. 3B).
Figure 3. The $l d$ gene encodes nuclear proteins. $(A)$ The nuclear localization of the $l d$ gene products is revealed by immunofluorescent labeling of chicken embryonic fibroblasts using FP1 antiserum. Note the punctate nuclear staining, whereas the antigen is cytoplasmic in mitotic cells (arrowheads). ( $A^{\prime}$ ) Counterstaining of the same cells with Hoechst 33258 to reveal nuclei and chromosomes. Arrowheads in $A$ and $A^{\prime}$ indicate mitotic figures. $(B)$ Staining of a transverse section of an embryonic stage-21 limb bud with FP1 antiserum. Due to immunocomplexing with horseradish peroxidase, nuclei expressing the $l d$ antigen appear as black spots, whereas negative nuclei appear bright due to counterstaining with Hoechst 33258 . $\left(B^{\prime}\right)$ FP1 antiserum is depleted of specific ld ORF antibodies (see Materials and methods), and an adjacent section is stained to reveal nonspecific background labeling. (E) Extraembryonic membranes; (LB) limb bud; (M) myotome; (N) notochord; (MN) mesonephros; (G) hind gut.

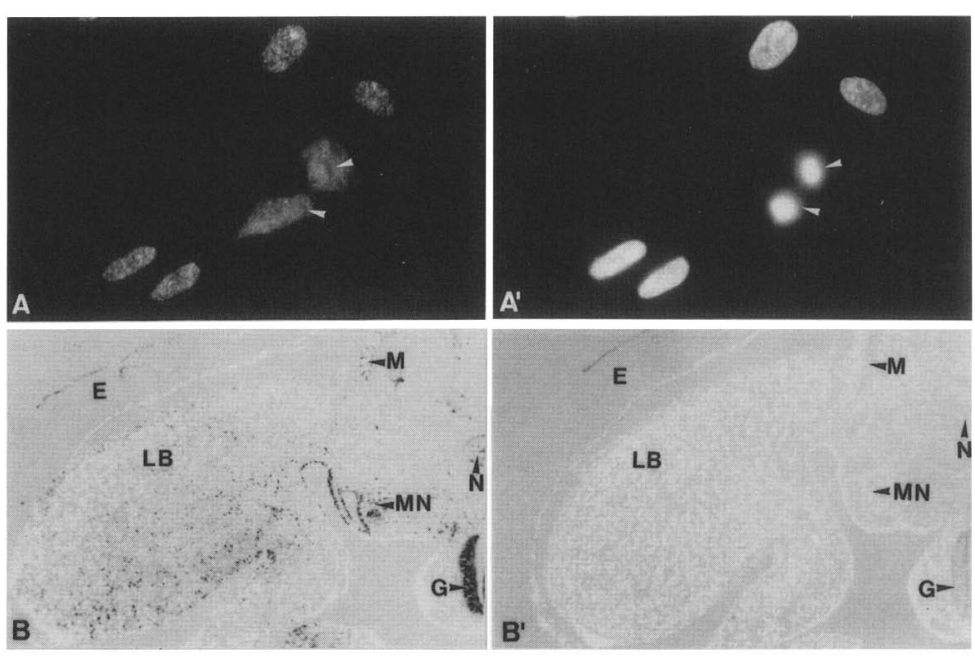


For each embryonic stage, serial sections of several embryos were analyzed in independent experiments to show reproducibility of the observed staining patterns (Figs. 3-7). Specificity was routinely checked by depleting the FP1 antiserum of its specific antibodies prior to application on embryo sections (Fig. 3B'; for details, see Materials and methods). Sections (Fig. $3 \mathrm{~B}^{\prime}$ ) or cultured cells (data not shown) incubated with depleted antiserum no longer show any nuclear staining, but low levels of cytoplasmic background staining remain in certain cell types (Fig. 3B'; myotome, notochord, gut, extra embryonic membranes). This control further validates the conclusion that all of the $1 d$ gene products seen by immunohistochemical analysis are nuclear proteins.

\section{Primary expression in embryonic mesoderm during somitogenesis}

By stage 15 of chicken embryonic development (Fig. 4A, $50 \mathrm{hr}$ of incubation; Hamburger and Hamilton 1951), most of the trunk structures, including prospective limb fields and pronephros, have been determined and somitogenesis is in progress. High levels of the $l d$ antigen are seen in the notochord and pronephros (Fig. 4B,C), whereas no expression is seen in the neural tube or presomitic mesenchyme. Analysis of earlier developmental stages reveals staining of the notochord as early as stage 12 ( $45 \mathrm{hr}$ ), suggesting that this is the primary mesodermal site expressing the $1 d$ gene (data not shown). At the same stage, diffuse staining of the head neuroepithelium is seen (data not shown).

In stage 15 embryos, the $1 d$ gene products are also expressed in cells of the differentiating dermamyotome of the more anterior somites (Fig. 4D), whereas no signal is seen in the most posterior somites (Fig. 4B-D). As a result of the anteroposterior polarity of somitogenesis (Patten 1957), the newly formed posterior somites consist of undifferentiated epithelium, whereas anterior somites already show differentiation into sclerotome, dermatome, and myotome. Analysis of later embryos (Fig. 7A,C below) reveals persistent expression in the myotome. In still older embryos, expression is seen in multinucleated myotubes (data not shown), suggesting possible roles for the $l d$ gene products in myogenesis.

\section{Expression in the epithelial compartment during early kidney morphogenesis}

Analysis of stage 14 embryos $150 \mathrm{hr}$; Hamburger and Hamilton 1951) reveals expression of the $1 d$ gene products in the developing pronephros, but no signal is seen in the underlying intermediate mesenchyme (Fig. 5A,B). The primordium of the pronephros arises as a bud of cells from the intermediate mesenchyme and will give rise to the epithelial compartment of the urinary system (Patten 1957). The observed pattern indicates that expression is restricted to this newly formed compartment. During later developmental stages (Fig 5C-E), the degenerating pronephros is replaced by the differentiating mesonephros (Saxén 1987). Expression of the $1 d$ gene products persists in the epithelial compartment, which consists of mesonephric ducts and tubules (Fig. 5C-E). Furthermore, $1 d$ proteins are expressed in developing glomerulei (arrow, Fig. 5C) and scattered mesenchymal cells (Fig. 5CE).

In addition to mesodermal expression, positive cells are seen in the ectoderm overlying the mesonephros at stage 18 (Fig. 5C). By stage 22 (3.5 days), all ectodermal
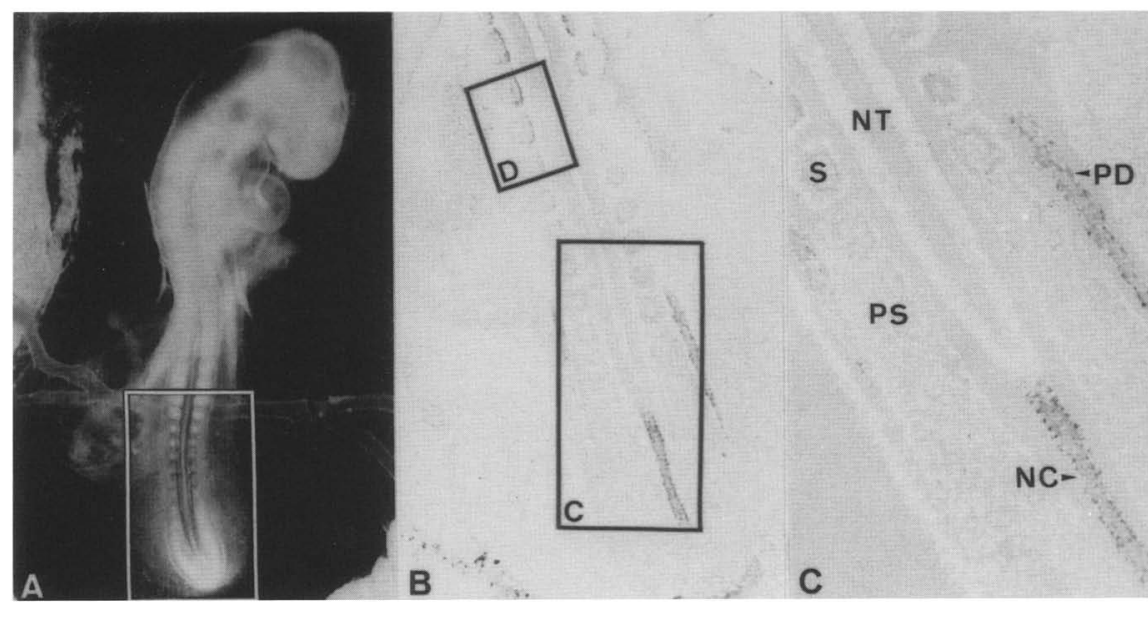

Figure 4. Primary mesenchymal sites of expression. (A) Photograph of a stage-15 chicken embryo prior to processing for immunohistochemistry. Frame indicates the approximate plane of the section shown in $B .(B)$ A horizontal section (slightly slanted) through the trunk region of a stage-15 chicken embryo is stained with FPl antiserum to reveal expression of the $l d$ proteins (dark nuclei). Frames indicate the enlargements shown in $C$ and $D$. Note the craniocaudal polarity of somitogenesis $($ see $A, B) .(C)$ Expression in the notochord (NC) and pronephric ducts (PD). (NT) Neural tube; (S) somite; (PS) presomitic mesenchyme. $(D)$ Expression is restricted to the dermamyotome of the developmentally more advanced anterior somites (S). Arrowheads indicate the forming dermamyotome. (NT) neural tube; (ant) anterior; (post) posterior. All sections (except $B$ ) are counterstained with Hoechst 33258 to reveal nonexpressing cells. 


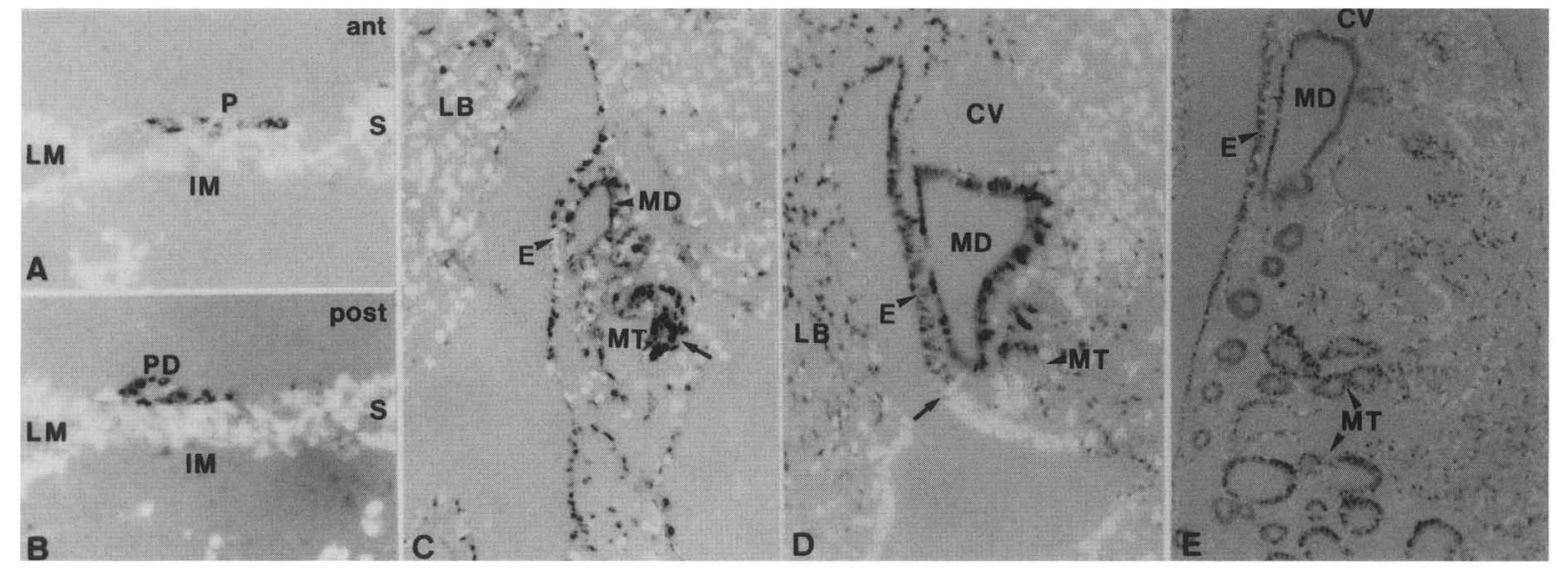

Figure 5. Expression during kidney morphogenesis. $(A, B)$ Transverse sections through the trunk region of a stage-14 embryo reveal $1 d$ proteins in the pronephros (P). B is more posterior than $A$ to show expression in the pronephric duct (PD). Note that expression (dark nuclei) is restricted to the pronephric compartment of the intermediate mesenchyme (IM). (LM) Lateral plate mesenchyme; (S) somite; (ant) anterior; (post) posterior. (C-E) Expression in the developing mesonephros. (MD) Mesonephric duct; (MT) mesonephric tubules; (E) ectoderm; (LB) limb bud; (CV) posterior cardinal vein. (C) Transverse section of a stage-18 embryo reveals expression in the mesonephric ducts and tubules. The arrow indicates expression in a developing glomerulus. ( $D$ Transverse section of a stage-22 embryo. Note the sharp boundary of expression in the ectoderm contacting the mesonephric duct (arrow). (E) Transverse section of a mesonephros (embryonic stage 28). Note the scattered positive mesenchymal cells in addition to expression in ducts, tubules, and ectoderm. All sections are stained with FPl antiserum and Hoechst 33258.

cells in close proximity to the mesonephric ducts express $l d$ proteins and a sharp ventral boundary (arrow, Fig. 5D) separates positive from negative cells. The coordinated expression of $l d$ gene products in the mesodermal and ectodermal compartments suggests the occurrence of a homeogenetic induction process between the two germ layers (for review, see De Robertis et al. 1989). Expression in the mesonephros and its overlying ectoderm persists through the oldest embryonic stages analyzed (Fig. 5E; stage 28 or 5.5 days). Expression of the $1 d$ gene products during development of the late metanephric kidney has not been studied, but Western blot analysis (Fig. 2B) reveals the presence of $l d$ proteins in adult kidneys.

\section{Motor neuron induction and expression of the ld gene products}

The notochord marks the primary craniocaudal axis of vertebrate embryos and participates in the inductive processes leading to establishment of the dorsoventral neural tube polarity (van Straaten et al. 1985a). First, the notochord induces the floor plate of the neural tube, and a sequence of inductive events (involving the notochord and floor plate) then lead to determination of the motor neurons (van Straaten et al. 1985b, 1988; Yamada et al. 1991).

The $1 d$ protein distribution in the notochord and neural tube was studied by analyzing serial transverse sections through the trunk region of the different embryonic stages shown in Figure 6. The $1 d$ antigen is already expressed in the notochord by stage 12 (see above), which is after completion of gastrulation (Hamburger and Hamilton 1951). Continuous expression is seen in the notochord throughout establishment of the dorsoventral neural tube axis (Fig. 6). Initially, no expression is seen in the caudal part of a stage $14(50 \mathrm{hr})$ neural tube (Fig. 6A), whereas scattered positive cells are seen in the cranial parts (data not shown). No labeling of floor-plate cells is seen. About $12 \mathrm{hr}$ later (stage 17), Id proteins are present in the morphologically distinct floor-plate cells of the neural tube. Floor-plate staining is very strong during stages 18 (Fig. 6B) and 19 (data not shown) but begins to decrease thereafter. Expression in the floor plate is therefore transient and is no longer seen at stage 22 (Fig. 6C). Furthermore, scattered positive cells are present in other regions of the developing neural tube during these stages (Fig. 6B,C and data not shown). By stage 22 most of the motor neurons have been determined and differentiate in the ventral horn regions of the neural tube. Very high levels of $l d$ antigen are seen in these areas (Fig. 6C). Expression in the ventral horns and mantle layer persists through the latest stage analyzed (Fig. 6D; stage 28 or 5.5 days 1 . These areas consist of differentiating motor neurons and neuroblasts that will eventually form the gray matter. No expression is seen in the ependymal layer of the neural tube, but high levels of antigen are seen in differentiating spinal ganglia (Fig. 6D).

\section{Unequal distribution of ld gene products during limb pattern formation}

The limb buds of chicken embryos arise as thickenings of the lateral plate mesoderm during stage $17(60 \mathrm{hr}$; Hamburger and Hamilton 1951). The AER differentiates 
into a pseudostratified columnar epithelium at the distal tip (for review, see Fallon et al. 1983); and during subsequent stages (18-22, days 3-4), the anteroposterior limb pattern is determined. Later in limb development (stage 22 onwards), the blastemal condensations form and differentiating chondrocytes deposit the cartilage models of the limb skeletal elements.

In embryonic stage 18 limb buds (Fig. 7A), high levels of $l d$ gene products are seen in all cells of the recently differentiated AER. Preliminary analysis suggests that expression in the AER persists through later stages but becomes restricted to the basal cell layer (see, e.g., Fig. $7 \mathrm{C}$. In addition, expression is seen in scattered cells of the undifferentiated limb ectoderm during early limbbud stages (data not shown).

The spatial distribution of the $l d$ antigen in limb-bud mesenchymal cells undergoes dramatic changes during morphogenesis (Fig. 7). The initially scattered expression (stage 18, Fig. 7A) changes into a clearly unequal distribution along the anteroposterior axis by embryonic stage 19 (Fig. 7B). Interestingly, most of the positive cells are located in the posterior part of the limb bud containing the ZPA, which is known to specify the positional information of the anteroposterior limb axis (for review, see Tickle 1991). No antigen is detected in the most anterior cells. This pattern changes into a strikingly unequal dorsoventral distribution by stage 22 (Fig. $7 \mathrm{C}, \mathrm{D}$ ). Ventral cells are strongly positive, whereas dorsal mesenchymal cells do not express the $1 d$ gene (Fig. 7 C). Expression along the anteroposterior axis is now restricted to the core mesenchyme of the ventral part (Fig. 7D). As development proceeds, expression of the ld protein is gradually restricted to condensations of the forming long bones (Fig. 7E) and digits (Fig. 7F). All cartilage-producing chondrocytes are positive, whereas most cells of the surrounding perichondrium are negative (Fig. 7E). Only a few cells of the nonchondrogenic distal mesenchyme express the antigen (Fig. $7 \mathrm{~F}$; ectoderm staining is nonspecificl, but expression is also seen in differentiating myoblasts and probably in forming tendons (data not shown). A detailed evaluation of the results obtained by this study with respect to the murine $1 d$ phenotype is given below.

\section{Discussion}

\section{The ld gene encodes novel nuclear proteins}

This study describes the isolation and molecular analysis of a 5-kb chicken embryonic $1 d$ transcript (Fig. 1). For the first time, the existence of proteins encoded by the $1 d$ gene, their nuclear localization, and their temporal and spatial expression patterns during chicken embryonic development are demonstrated.

The cloned $180-\mathrm{kD}$ chicken embryonic $1 d$ protein (Figs. 1 and 2) shows no significant homology to known DNA-binding motifs (for review, see Churchill and Travers 1991), with the exception of the proline-rich "hinge" region, which shows homology to several tran- scription factors (Woychik et al. 1990a; B. Altenberg and C. Sander, pers. comm.). The nuclear localization of the ld gene products (Fig. 3) suggests a role in regulation of gene expression during embryonic development. Other nuclear components, such as certain transcription factors (e.g., c-myc; Spector et al. 1987) and nuclear ribonucleoprotein particles [e.g., small nuclear RNPs (snRNPs); Carmo-Fonseca et al. 1991], also show a punctate distribution pattern. However, colocalization studies using specific anti-snRNP antibodies have so far shown no significant overlap with the $1 d$ antigen in cultured cells (A. Trumpp and R. Zeller, unpubl.). Furthermore, the temporal and spatial expression of the $1 d$ proteins during embryogenesis and their punctate nuclear pattern argues against them being a ubiquitous structural component of the nucleus. Analysis of the $1 d$ proteins reveals no significant similarities to any previously studied nuclear protein; therefore, it seems likely that the $I d$ gene products are members of a novel class of proteins. Analysis of their expression patterns (Figs. 3-7) provides an indication of their possible roles during embryonic development (see below).

\section{Involvement of the ld gene products in primary limb and kidney morphogenesis}

The temporal and spatial distributions of the $1 d$ gene products during chicken limb pattern formation (Fig. 7) indicate a possible explanation for the nature of the observed murine $1 d$ phenotype and suggest roles for the $1 d$ gene products during patterning and differentiation. Morphological analysis of murine $l d$ embryos revealed shortening of the anteroposterior limb axis (accompanied by necrosis of the mesenchymal cells) and a lack of complete AER differentiation during determination of the primary limb pattern. Reductions and fusions of the skeletal elements of the hand and foot plates were found to be primary defects, whereas fusion of the ulna and radius occurs at the onset of ossification (Zeller et al. 1989).

Analysis of expression of the $1 d$ gene in early mouse limb buds reveals two alternatively spliced transcripts. The murine $1 d$ mRNA homologous to the cloned chicken transcript (Fig. 1) is expressed in both the mesenchymal and ectodermal compartments, whereas the second transcript is only expressed in the limb ectoderm (Jackson-Grusby et al., this issue). The level of $l d$ transcripts in early limb-bud ectoderm is approximately fivefold higher than in its mesenchyme (Zeller et al. 1989). These results are in agreement with the observed high levels of $l d$ proteins in cells of the newly differentiated AER in chicken embryos (Fig. 7A). In correlation with the mutant phenotype, this expression pattern points to an essential role of the $1 d$ gene products in differentiation and maintenance of the AER. The ld phenotype, together with the unequal distribution of the $l d$ gene products along the anteroposterior axis in the limb mesenchyme (Fig. 7B) during the time when polarity of this axis is established (for review, see Eichele 1990; Tickle 1991), 

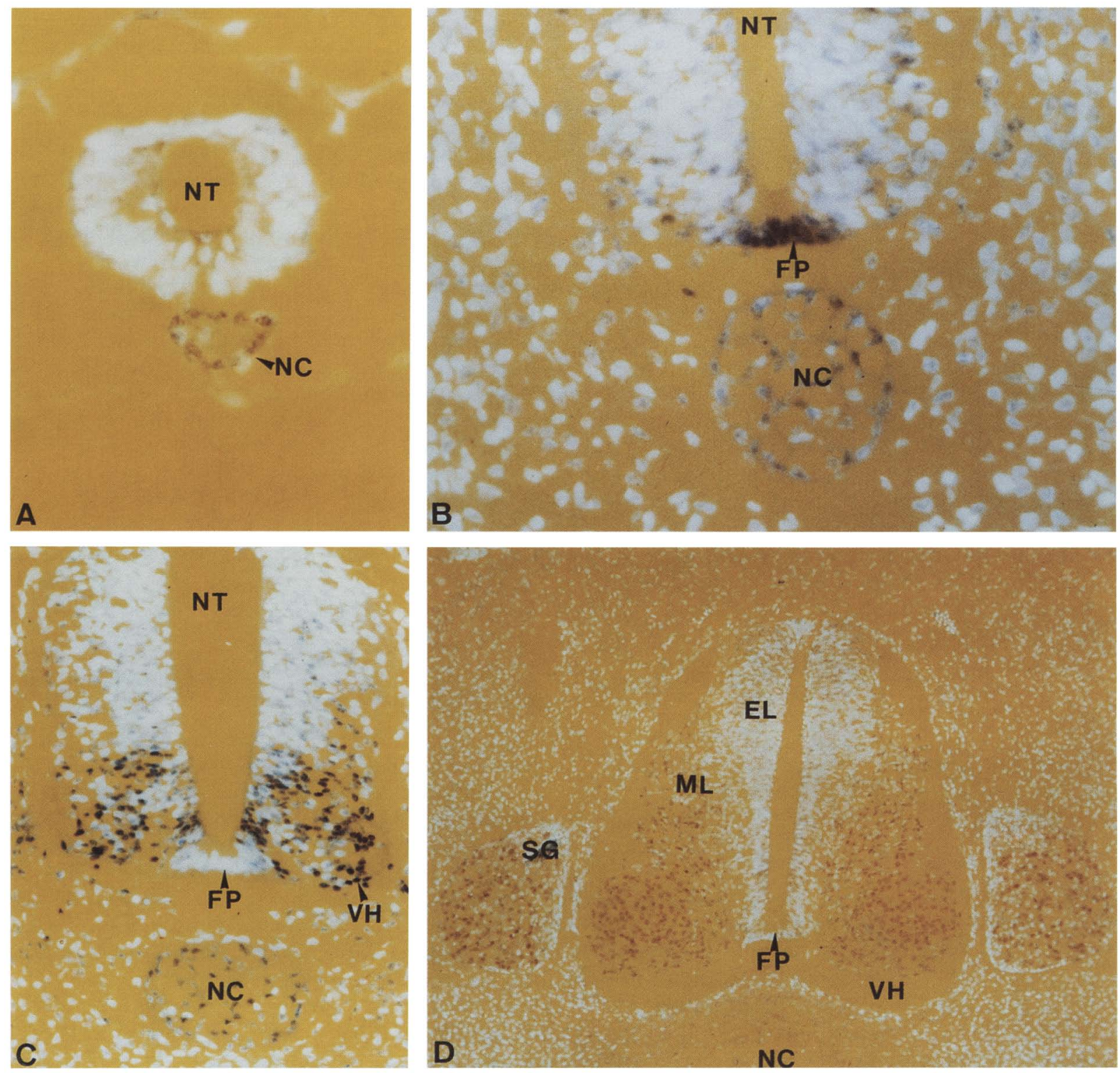

Figure 6. Expression during motor neuron induction. All sections shown are transverse and are stained with FPl antiserum and counterstained with Hoechst 33258. The antigen is visualized by brown or black staining of nuclei, whereas nuclei of nonexpressing cells appear bright. All sections are representative for the distribution patterns observed in the trunk regions (between wing and leg limb bud) of the different embryonic stages. (NC) Notochord; (NT) neural tube; (FP) floor plate: (VH) ventral horn; (ML) mantle layer; (EL) ependymal layer; (SG) spinal ganglia (dorsal root ganglia). (A) The notochord and neural tube in the posterior trunk region of a stage-14 embryo. $(B)$ ld protein distribution in the notochord and floor plate of a stage-18 embryo. $(C)$ The notochord and neural tube at stage 22. Intense labeling of cells in the ventral horn regions of the neural tube is seen. Note that the floor plate cells are negative. (D) Expression in the neural tube and spinal ganglia of a stage-28 embryo.

Figure 7. Temporal and spatial distribution of the $1 d$ gene products during limb morphogenesis. All limb-bud sections shown are stained with FP1 antiserum and Hoechst 33258. Schemes indicate the planes of all sections shown, and all relevant axes are indicated in $A-F$. (ant) Anterior; (post) posterior; (prox) proximal; (dist) distal; (dors) dorsal; (ven) ventral; (MY) myotome; (MN) mesonephros; (AER) apical ectodermal ridge; (CO) condensation (chondrocytes); $(\mathrm{PC})$ perichondrium. $(A)$ Transverse section of a stage-18 limb bud. $(B)$ Horizontal section of a stage-19 limb bud. $(C)$ Transverse section of a stage-22 limb bud. $(D)$ Longitudinal section of a stage- 23 limb bud. (E) Cross section through a cartilage condensation (either ulna or radius) of a stage-28 embryo. $(F)$ Cross section of a developing foot plate (stage-28 embryo) showing condensations of the forming digits. 

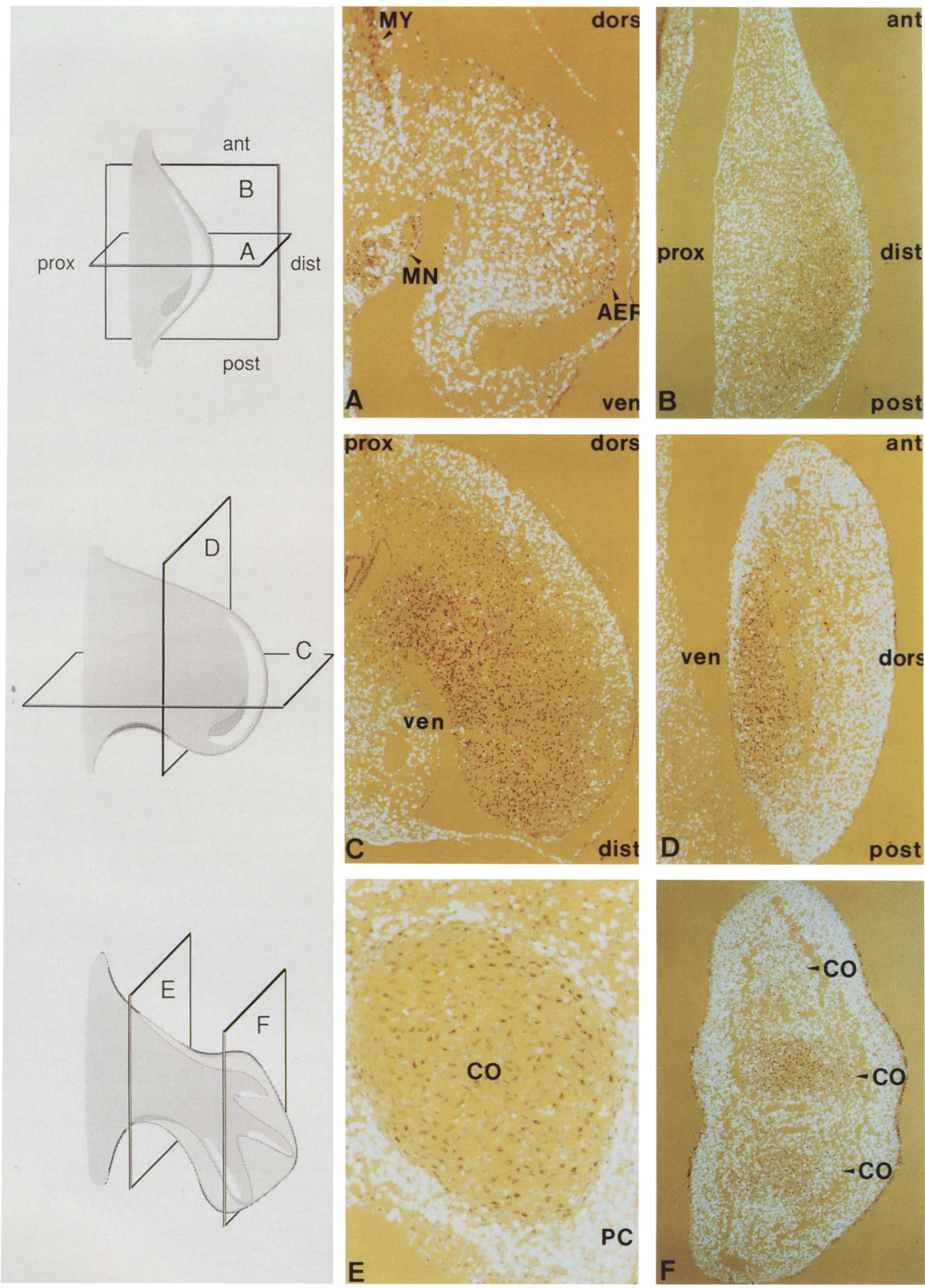

rigure $\%$ [Jee tacing page for legena.

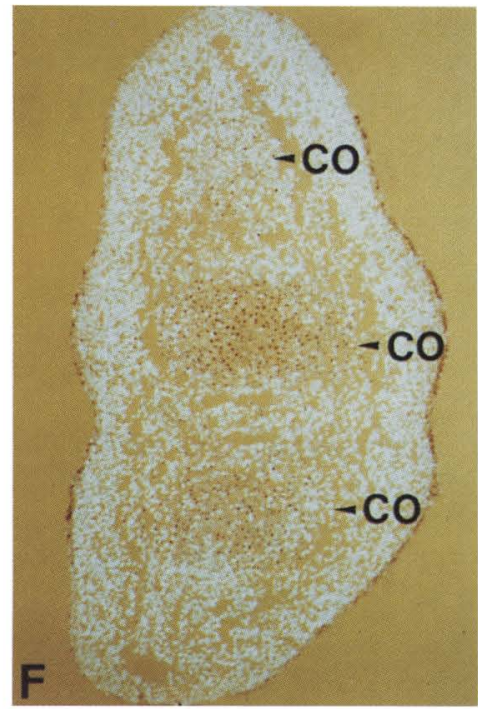


suggest that the proteins are involved in limb-pattern formation. The much higher number of cells expressing the $I d$ gene products in the posterior part of the limb bud suggests that their expression is controlled by the morphogenetic activity of the ZPA (Wolpert 1969). It is therefore possible that the $1 d$ proteins are involved in mediating cellular response to a morphogen, which leads to determination of positional information in the limb bud (as suggested for the Hox-4 gene cluster; Dollé et al. 1989). Subsequently, this pattern changes into a strikingly unequal distribution along the dorsoventral axis (Fig. 7C,D). In contrast to patterning of the anteroposterior limb axis, very little is known about dorsoventral patterning; however, experiments by MacCabe et al. (1974) show control by the limb ectoderm. The observed ventral expression of the $1 d$ proteins might allow analysis of the epithelial-mesenchymal interactions that determine dorsoventral polarity at a molecular level. Continuing expression in the chondrocyte lineage during the formation of blastemal condensations and chondrogenesis (Fig. 7E,F) implies a role during the processes leading to formation of the limb skeletal elements. These data suggest that continuous $l d$ expression may be necessary to avoid secondary fusions of the skeletal elements during subsequent ossification, as is observed in murine $1 d$ embryos (Kleinebrecht et al. 1982; Zeller et al. 1989)

In addition to the limb phenotype, a high frequency of uni- or bilateral renal aplasia is observed in $l d$ mice. The observed renal aplasias are linked to a deficiency in correct outgrowth of the ureteric bud (Woychik et al. 1990b; Maas et al. 1991), which probably leads to a failure in the induction of tubular differentiation. The nature of the observed lesions suggests a defect in the epithelial compartment from which the ureter is derived (see Saxén 1987). The data presented here demonstrate that expression of the $1 d$ proteins is initially restricted to the epithelial compartment of the forming embryonic kidney (Figs. 4 and 5). Maas et al. (1991) have shown high levels of $l d$ transcripts in human fetal kidneys of 20 weeks gestation. Together with the murine $l d$ phenotype, these data suggest participation of the $1 d$ gene products in the earliest events mediating epithelial-mesenchymal interactions during kidney morphogenesis.

Expression of the $1 d$ gene in chicken embryos is not restricted to developing limbs and kidneys, as would be expected from the murine $1 d$ phenotype. The temporal and spatial expression patterns, particularly in the notochord and neural tube but also in other embryonic structures, suggest roles for the $1 d$ gene products in their morphogenesis (see below). It is possible that a relatively weak $l d$ phenotype in any of these structures has been missed in the phenotypic analysis, which has only focused on limbs and kidneys (Kleinebrecht et al. 1982; Woychik et al. 1985; Zeller et al. 1989). Alternatively, it is likely that the different murine $1 d$ alleles either represent an incomplete loss-of-function phenotype or that the mutation is partially compensated for by other genetic loci (for more details, see Maas et al. 1990). To discriminate between these different possibilities, further genetic analysis will be necessary. ld gene products may be involved in determining dorsoventral neural tube polarity and motor neuron induction

Gastrulation in vertebrates induces formation of the notochord, which represents the primary mesenchymal site of $1 d$ gene expression (Figs. 4 and 6A). The notochord has an instructive role in organizing dorsoventral polarity of the neural tube (van Straaten et al. 1985a) by inducing formation of the floor plate and motor neurons (for review, see Lumsden 1991). The notochord is able to induce the floor plate up to about stage 13; thereafter this competence is progressively lost (van Straaten et al. 1988). Subsequently, the notochord, together with the floor plate, becomes the main mediator for induction of dorsoventral polarity and motor neuron differentiation in the neural tube (Yamada et al. 1991). 1d gene products are seen in floor-plate cells of the trunk region (Fig. 6B) from approximately stages 17 to 20 . This transient expression might indicate a temporary competence of the floor plate to mediate the inductive processes leading to determination of motor neuronal cell fate in the developing spinal cord. Furthermore, high levels of $1 d$ proteins are seen in the ventral horns at the time of motor neuron differentiation (Fig. 6C). The successive appearance of the $l d$ antigen in the notochord, the floor plate and, finally, the motor neurons suggests homeogenetic induction (for review, see De Robertis et al. 1989) and points to a role for the $1 d$ gene products in determination of motor neuronal cell fate. Further experimentation is necessary to decipher the function of the $l d$ gene products in these processes.

The observed expression patterns in the notochord and neural tube, the pronephros and mesonephros, and the limb buds suggest a possible involvement of the ld gene products in mediating response to the morphogenetic signals that govern pattern formation and lead to subsequent differentiation. The signals controlling these determinative steps seem to be closely related because transplantation of notochord (Hornbruch and Wolpert 1986), floor plate (Wagner et al. 1990), or mesonephric (Saunders 1977) tissues to the limb bud reveals their ability to mimic the morphogenetic activity produced by the ZPA (for review, see Tickle 1980; see also introductory section). Therefore, it seems possible that induction of $l d$ expression in these different embryonic structures is controlled by similar or identical morphogenetic signals. Furthermore, expression of the $l d$ gene persists into adulthood in specific organs (Fig. 2A,B; Woychik et al. 1990a). Therefore, $l d$ gene products could also have a function in differentiated cells or be involved in maintaining specific differentiated states. This study identifies the major embryonic $1 d$ gene products and provides the basis for further elucidation of their biochemical functions and precise roles during morphogenesis.

\section{Materials and methods}

Embryos

Chicken eggs (white leghorn) were incubated and staged according to Hamburger and Hamilton (1951). 


\section{Embryonic cDNA Libraries}

A cDNA library was made in Lambda ZAPII (Stratagene; following protocols adapted from Ausubel et al. 1987), using poly $(\mathrm{A})^{+}$RNA prepared from stages $19-23$ total chicken embryos. The unamplified library had a complexity of $\sim 4.5 \times 10^{6}$ clones with an average insert size of $2 \mathrm{~kb}$. This library was repeatedly screened as described in Results. Duplicate GeneScreen Plus filters (New England Nuclear/DuPont) were hybridized and washed following standard procedures. Rescued Bluescript pSK plasmids (Stratagene) were sequenced using a Sequenase version 2.0 kit (U.S. Biochemical). A chicken embryonic cDNA library obtained from B. Vennström (Sap et al. 1986) was also screened for $l d$ cDNAs, and three partial cDNA clones were isolated.

The nucleotide sequence of the ORF has been deposited in the EMBL, GenBank, and DDBJ nucleotide sequence data bases under accession number X62681.

\section{RNA analysis}

Embryos or tissues were explanted into liquid nitrogen and stored at $-70^{\circ} \mathrm{C}$. RNA was prepared as described previously (Zeller et al. 1989). RNA concentrations were determined by $\mathrm{OD}_{260 / 280}$ measurements, and samples were normalized for their poly $(\mathrm{A})^{+}$RNA content by hybridization to poly $\left.{ }^{3} \mathrm{H}\right] \mathrm{UTP}$ (Rosbash and Ford 1974) before use.

RNase protection assays (Melton et al. 1984) were performed using an antisense $\left[{ }^{32} \mathrm{P}\right] \mathrm{UTP}$-labeled riboprobe (probe 1, Fig. 1B), or an antisense chicken $\beta$-actin probe (Kost et al. 1983) to check for RNA integrity.

Poly $(\mathrm{A})^{+}$RNA was prepared from $500 \mu \mathrm{g}$ of total embryonic RNA for Northern analysis. Samples were normalized for poly $(\mathrm{A})^{+}$content, electrophoresed on a $1 \%$ formaldehyde-agarose gel, and transferred to GeneScreen filters (New England Nuclear/DuPont). The filters were hybridized with different probes (Fig. 1B) and stripped according to standard procedures.

\section{In vitro transcription and translation}

The complete embryonic $1 d$ ORF (Fig. 1A) was assembled inframe from three overlapping cDNAs. The composite cDNA was cloned into the Bluescript $\mathrm{pKS}$ vector (Stratagene). The plasmid was linearized at the $3^{\prime}$ end of the $l d$ ORF and transcribed using T3 RNA polymerase (Boehringer Mannheim) in the presence of 7-methyl-guanosine cap analog according to Nielsen and Shapiro (1986). Four micrograms of transcript was used for in vitro translation $\left(1 \mathrm{hr}\right.$ at $\left.30^{\circ} \mathrm{C}\right)$ in nuclease-treated rabbit reticulocyte lysate (Promega). The synthesized proteins were labeled by $\left[{ }^{35} \mathrm{~S}\right]$ methionine $(40 \mu \mathrm{Ci} /$ reaction, Amersham).

In vitro-translated proteins were immunoprecipitated with the FP1 antisera (see below) using protein A-Sepharose beads (CL4B, Pharmacia) as described by De Robertis et al. (1982).

\section{Preparation of antisera}

A total of 251 amino acids of the $1 d$ ORF (FP1, Fig. 1B) were cloned in-frame into the expression vector $\mathrm{pEX} 34 \mathrm{a}$. The fusion protein consists of the most carboxy-terminal part of the ld ORF fused to the amino-terminal $10 \mathrm{kD}$ of the phage MS2 polymerase (Klinkert et al. 1988). Induction, extraction, and purification of fusion proteins were performed as described by Klinkert et al. (1988). For the first and second injections into rabbits, 100-200 $\mu \mathrm{g}$ of purified fusion protein (mixed with Freund's adjuvant) was used, and half of this amount was used for all subsequent injections. Rabbits were boosted four times, and for most experi- ments the fourth bleed /collected 10 weeks after the initial injection) was used. The antiserum against the FP2 domain (Fig. 1B) was prepared in the same way.

\section{Affinity purification of antibodies}

For affinity purification, a second fusion protein consisting of $\beta$-galactosidase and either the FP1 or FP2 fragment (Fig. 1B) was constructed using the expression vectors pUR 288 and pUR 290 (Rüther and Müller-Hill 1983). The use of the $\beta$-galactosidase fusions in addition to the MS2 fusions allows easy purification of antibodies specific to the $1 d$ ORF. $\beta$-Galactosidase fusion proteins were purified as described (Carroll and Laughon 1987), electrophoresed on 7.5\% 30:1 SDS-polyacrylamide gels (Laemmli 1970), and transferred to nitrocellulose (BA85, Schleicher \& Schuell). Filters were stained with Ponceau S (Serva) and the strip containing the fusion protein was removed and used for the subsequent affinity purification of $l d$-specific antibodies. Strips were preincubated for $10 \mathrm{~min}$ in blocking solution $110 \%$ newborn calf serum plus $0.3 \%$ Tween 20 in PBS) and incubated overnight at $4{ }^{\circ} \mathrm{C}$ with crude antiserum (diluted $1: 10$ in blocking solution|. The strips were subsequently washed in blocking solution for $5 \mathrm{~min}$, followed by PBS for $5 \mathrm{~min}$ and $150 \mathrm{mM} \mathrm{NaCl}$ for $2 \mathrm{~min}$. Bound antibodies were eluted for $5 \mathrm{~min}$ in elution buffer I [ $5 \mathrm{~mm}$ glycine plus $0.5 \mathrm{M} \mathrm{NaCl}(\mathrm{pH} 2.8)]$ and then for 5 min in elution buffer II [ $5 \mathrm{~mm}$ glycine plus $0.5 \mathrm{M} \mathrm{NaCl}$ (pH 2.2)]. Eluants were immediately neutralized by adding $10 \% 2 \mathrm{M}$ Tris$\mathrm{HCl}(\mathrm{pH} 8.0)$ and $5 \%$ newborn calf serum, and stored in aliquots at $-70^{\circ} \mathrm{C}$. Such affinity-purified antibodies were used for immunoblotting or immunofluorescence.

\section{Protein extracts}

Embryos and organs were explanted into liquid nitrogen and homogenized in ice-cold PBS containing $0.3 \mathrm{mM}$ PMSF. SDS to a final concentration of $2 \%$ and $\beta$-mercaptoethanol to $5 \%$ were then added. Extracts were sonicated extensively and liquified further using needles of increasing gauge $(21,22,25)$ and boiled for $10 \mathrm{~min}$. Aggregates were removed by centrifugation, and glycerol to a final concentration of $10 \%$ plus Tris- $\mathrm{HCl}(\mathrm{pH} 8.0)$ to $0.12 \mathrm{M}$ were added to the supernatants. Extracts were stored in aliquots at $-70^{\circ} \mathrm{C}$. The integrity of the isolated proteins was checked, and concentrations were normalized by staining $7.5 \%$ $30: 1$ SDS-polyacrylamide gels with Coomassie brilliant blue. About $50 \mu \mathrm{g}$ of proteins were used for immunoblotting analysis.

\section{Immunoblotting}

Equal amounts of extracts were separated on $7.5 \% 30: 1$ SDSpolyacrylamide gels, transferred to nitrocellulose using $1 \mathrm{~A}$ (constant current) for $2 \mathrm{hr}$ at $4^{\circ} \mathrm{C}$, and checked by Ponceau $\mathrm{S}$ staining. Nonspecific binding sites were blocked by incubation in M-block solution $\left(20 \mathrm{mM} \mathrm{MgCl}_{2}, 10 \%\right.$ newborn calf serum, $0.3 \%$ Tween 20 in PBS) three times for $10 \mathrm{~min}$. Blots were incubated for $2 \mathrm{hr}$ at room temperature with affinity-purified antibodies diluted in M-block solution. An affinity-purified goat anti-rabbit antiserum coupled to alkaline phosphatase (Promega) was used as the secondary antibody for $1 \mathrm{hr}$ at room temperature. Blots were washed three times for $10 \mathrm{~min}$ in M-block solution following each incubation with antiserum. The protein-antibody complexes were visualized by an alkaline phosphatase reaction using color reagents (Harlow and Lane 1988). 


\section{Preclearing crude antisera}

Because the $1 d$ gene is not expressed in chicken liver (Fig. 2B), liver acetone powder can be used to reduce the titer of nonspecific antibodies in crude antisera. Preparation of acetone powder and preabsorption of crude antisera were done according to Harlow and Lane (1988). Nonspecific complexes were removed by centrifugation, and the cleared supernatants were used for immunohistochemistry.

\section{Immunofluorescence}

Primary chicken embryonic fibroblasts (isolated from day-11 embryos) were grown on coverslips for $36 \mathrm{hr}$, and rapidly growing cells were fixed in ethanol-acetic acid $(95 \%: 5 \%)$ for $5 \mathrm{~min}$ at $-20^{\circ} \mathrm{C}$ or, alternatively, in $0.5 \%$ paraformaldehyde in PBS for $30 \mathrm{~min}$ at room temperature. Paraformaldehyde-fixed cells were further incubated in PBS containing $0.3 \%$ Triton X-100 for 5 min. Incubation with the FP1 antiserum was carried out in IF solution ( $3 \%$ BSA, $20 \mathrm{mM} \mathrm{MgCl}_{2}, 0.3 \%$ Tween 20 in PBS) for 1 $\mathrm{hr}$ at room temperature. After washing, the cells were incubated for 30 min with a secondary antibody coupled to rhodamine (goat anti-rabbit IgG, Cappel). After each incubation with antiserum the cells were washed three times in $0.2 \%$ gelatine plus $1 \%$ Triton X-100 in PBS. Nuclei were counterstained with 5 $\mu \mathrm{g} / \mathrm{ml}$ of bis-benzimid (Hoechst 33258) for $5 \mathrm{~min}$. After a final wash, the coverslips were mounted using Mowiol (Hoechst).

\section{Immunohistochemistry}

Embryos were dissected in ice-cold PBS and fixed in freshly prepared $4 \%$ paraformaldehyde in PBS for $30-90 \mathrm{~min}$ at $4^{\circ} \mathrm{C}$ Embryos of stages 19 or older (Hamburger and Hamilton 1951) were pinned on a solid support during fixation to allow correct orientation of all body and limb axes. Following fixation, embryos were dehydrated and embedded in Histosec wax (Reichert-Jung) following standard procedures (Zeller et al. 1987). Histological sections $(6 \mu \mathrm{m})$ were mounted on poly-L-lysinecoated slides. After dewaxing, the sections were treated for 2 min in ethanol-acetic acid $(95 \%: 5 \%)$ before rehydration. This treatment is essential to make the antigens available for the FPl antibodies. Endogenous peroxidases were quenched by incubating the sections for $45 \mathrm{~min}$ in methanol containing $0.3 \% \mathrm{H}_{2} \mathrm{O}_{2}$. After being washed in PBS, the sections were incubated for 30 min in H-block solution $15 \%$ goat serum, 3\% BSA, $20 \mathrm{~mm}$ $\mathrm{MgCl}_{2}, 0.3 \%$ Tween 20 in PBS|. Sections were incubated for $2 \mathrm{hr}$ at room temperature with FPl antiserum diluted in $\mathrm{H}$-block solution, rinsed in PBS, and washed twice with $1 \%$ Triton X-100 in PBS for $5 \mathrm{~min}$. The sections were then incubated with biotinylated goat anti-rabbit IgG (Vectastain kit, Vector labs) for 30 min, rinsed in PBS, and washed twice in $1 \%$ Triton X-100 in PBS for $5 \mathrm{~min}$. A final incubation with an avidin-horseradish peroxidase complex (Vectastain kit) was done for $45 \mathrm{~min}$. Following extensive washing with PBS, the signal was visualized by an HRP reaction, using diaminobenzidine $[1 \mathrm{mg} / \mathrm{ml}$ in $0.1 \mathrm{M}$ Tris$\mathrm{HCl}(\mathrm{pH} 7.2)]$ and $\mathrm{H}_{2} \mathrm{O}_{2}(0.03 \%$ final) as substrates. To increase the signal, duplicate slides were visualized, using developer containing $0.04 \% \mathrm{NiCl}_{2}$. Embryonic nuclei were counterstained with Hoechst $33258(50 \mu \mathrm{g} / \mathrm{ml})$. Sections were mounted and analyzed as described by Sundin and Eichele (1990).

\section{Depleting antisera of specific $\mathrm{ld}$ antibodies}

To check the specificity of the FPl antiserum for immunohistochemical studies, crude antiserum was specifically depleted of $l d$ antibodies by incubating diluted antiserum with an excess of purified MS2-FP1 fusion protein for $2 \mathrm{hr}$ at room temperature. After centrifugation the cleared supernatant was used for immunohistochemistry (see Fig. 3D).

\section{Acknowledgments}

We thank Carel Meijers for invaluable help in setting up the chicken system and assisting in the initial phase of this project. We thank Olaf Sundin, Gregor Eichele, and Thomas Schimmang for helpful hints in preparation and characterization of the antisera, Thanos Papavassiliou for help with the in vitro transcription and translation, and Karl-Heinz Friedrich for advice on immunoprecipitation. We are indebted to Björn Vennström for gifts of his chicken cDNA library and to Chris Sander and Brigitte Altenberg for carrying out DNA data base searches, secondary structure predictions, and careful evaluation of the results. We thank Laurie Jackson-Grusby and Philip Leder for sharing results prior to publication. We acknowledge Dirk Bohmann, Rosanna Dono, Denis Duboule, Thomas Graf, Philip Leder, Iain Mattaj, Marek Mlodzik, Carol Murphy and Aimée Zuniga Mejia Borja for helpful discussions and suggestions on the manuscript. Andreas Trumpp is the recipient of an EMBL predoctoral fellowship, and José Luis de la Pompa is supported by a postdoctoral grant from the Spanish Ministry of Science.

The publication costs of this article were defrayed in part by payment of page charges. This article must therefore be hereby marked "advertisement" in accordance with 18 USC section 1734 solely to indicate this fact.

\section{References}

Ausubel, F.M., R. Brent, R.E. Kingston, D.D. Moore, J.G. Seidman, J.A. Smith, and K. Struhl. 1987. Current protocols in molecular biology. Greene Publishing/Wiley-Interscience, New York.

Balling, R., U. Deutsch, and P. Gruss. 1988. Undulated, a mutation affecting the development of the mouse skeleton, has a point mutation in the paired box of Pax 1. Cell 55: 531535

Blundell, P.A., J.L. de la Pompa, J.H.C. Meijers, A. Trumpp, and R. Zeller. 1992. The limb deformity gene encodes evolutionarily highly conserved proteins. In Developmental patterning of the vertebrate limb (ed. J.R. Hinchliffe and D. Summerbell). (In press).

Carmo-Fonseca, M., R. Pepperkok, B.S. Sproat, W. Ansorge, M.S. Swanson, and A.I. Lamond. 1991. In vivo detection of snRNP-rich organelles in the nuclei of mammalian cells. EMBO /. 10: 1863-1873.

Carroll, S.B. and A. Laughon. 1987. Production and purification of polyclonal antibodies to the foreign segment of $\beta$-galactosidase fusion proteins. In DNA cloning: A practical approach (ed. D.M. Glover), pp. 89-112. IRL Press, Oxford, England.

Churchill, M.E.A. and A.A. Travers. 1991. Protein motifs that recognise structural features of DNA. Trends Biochem. Sci. 16: 92-97.

De Robertis, E.M., S. Lienhard, and R.F. Parisot. 1982. Intracellular transport of microinjected $5 S$ and small nuclear RNAs. Nature 295: 572-577.

De Robertis, E.M., G. Oliver, and C.V.E. Wright. 1989. Determination of axial polarity in the vertebrate embryo: Homeodomain proteins and homeogenetic induction. Cell 57: 189-191.

Dollé, P., J.C. Izpisúa-Belmonte, H. Falkenstein, A. Renucci, and D. Duboule. 1989. Coordinate expression of the murine 
Hox-5 complex homeobox-containing genes during limb pattern formation. Nature 342: 767-772.

Duboule, D. 1991. Patterning in the vertebrate limb. Curr. Opin. Gen. Dev. Biol. 1: 167-172.

Eichele, G. 1990. Pattern formation in vertebrate limbs. Curr. Opin. Cell Biol. 2: 975-980.

Fallon, J.F., D.A. Rowe, J.M. Frederick, and B.K. Simandl. 1983. Studies on epithelial-mesenchymal interactions during limb development. In Epithelial-mesenchymal interactions in development (ed. R.H. Sawyer and J.F. Fallon), pp. 3-25. Praeger Scientific, New York.

Grueneberg, H. 1963. The pathology of development. A study of inherited skeletal disorders in animals. Blackwell Scientific Publications, Oxford, England.

Hamburger, V. and H. Hamilton. 1951. A series of normal stages in the development of the chick embryo. J. Morphol. 88: 4992.

Harlow, E. and D. Lane. 1988. Antibodies: A laboratory manual. Cold Spring Harbor Laboratory, Cold Spring Harbor, New York.

Herrmann, B.G., S. Labeit, A. Poustka, T.R. King, and H. Lehrach. 1990. Cloning of the $\mathrm{T}$ gene required in mesoderm formation in the mouse. Nature 343: 617-622.

Hornbruch, A. and L. Wolpert. 1986. Positional signalling by Hensen's node when grafted to the chick limb bud. J. Embryol. Exp. Morphol. 94: 257-265.

Kleinebrecht, J., J. Selow, and W. Winkler. 1982. The mouse mutant limb-deformity (Id). Anat. Anz. 152: 313-324.

Klinkert, M.Q., A. Ruppel, R. Felleisen, G. Link, and E. Beck. 1988. Expression of diagnostic $31 / 32$ kilo dalton proteins of Schistosoma mansomi as fusions with bacteriophage MS2 polymerase. Mol. Biochem. Parasitol. 27: 233-239.

Kost, T.A., N. Theodorakis, and S.H. Hughes. 1983. The nucleotide sequence of the chick cytoplasmic $\beta$-actin gene. $\mathrm{Nu}$ cleic Acids Res. 11: 8287-8301.

Kozak, M. 1987. An analysis of 5' non-coding sequences from 699 vertebrate messenger RNAs. Nucleic Acids Res. 15: $8125-8148$.

Laemmli, U.K. 1970. Cleavage of structural proteins during assembly of the head of bacteriophage T4. Nature 277: 680685.

Lumsden, A. 1991. Motorizing the spinal cord. Cell 64: 471473.

Lyon, M.F. and A.G. Searle. 1989. Genetic variants and strains of the laboratory mouse. Gustav Fischer Verlag, Stuttgart, Germany.

Maas, R.L., R. Zeller, R.P. Woychik, T.F. Vogt, and P. Leder. 1990. Disruption of formin-encoding transcripts in two $\mathrm{mu}$ tant limb deformity alleles. Nature 346: 853-855.

Maas, R.L., L.I. Jepeal, S.L. Elfering, R.F. Holcombe, C.C. Morton, R.L. Eddy, M.G. Byers, T.B. Shows, and P. Leder. 1991. A human gene homologous to the formin gene residing at the murine limb deformity locus: Chromosomal location and RFLPs. Am. J. Hum. Genet. 48: 687-695.

MacCabe, J.A., J. Errick, and J.W. Saunders. 1974. Ectodermal control of the dorsoventral axis in the leg bud of the chick embryo. Dev. Biol. 39: 69-82.

McNeish, J.D., W.J. Scott Jr., and S.S. Potter. 1988. Legless, a novel mutation found in PHT1-1 transgenic mice. Science 241: 837-839.

Melton, D.A., P.A. Krieg, M.R. Rebagliati, T. Maniatis, K. Zinn, and M.R. Green. 1984. Efficient in vitro synthesis of biologically active RNA and RNA hybridization probes from plasmids containing a bacteriophage SP6 promoter. Nucleic. Acids Res. 12: 7035-7056.

Messing, A., R.R. Behringer, J.R. Slapeak, G. Lemke, R.D. Palm- iter, and R.L. Brinster. 1990. Insertional mutation at the $1 d$ locus (again!) in a line of transgenic mice. Mouse Genome 87: 107.

Nielsen, D. and D. Shapiro. 1986. Preparation of capped RNA transcripts using T7 RNA polymerase. Nucleic Acids Res. 14: 5936.

Patten, B.M. 1957. Early embryology of the chick. McGraw-Hill Book Company, New York.

Pohl, T.M., M.G. Mattei, and U. Rüther. 1990. Evidence for allelism of the recessive insertional mutation add and the dominant mouse mutation extra-toes (XT). Development 110: 1153-1157.

Rosbash, M. and P.J. Ford. 1974. Polyadenylic acid-containing RNA in Xenopus laevis oocytes. J. Mol. Biol. 85: 87-101.

Rüther, U. and B. Müller-Hill. 1983. Easy identification of cDNA clones. EMBO I. 2: 1791-1794.

Sap, J., A. Munoz, K. Damm, Y. Goldberg, J. Ghysdael, A. Leutz, H. Beug, and B. Vennström. 1986. The c-erb-A protein is a high-affinity receptor for thyroid hormone. Nature. 324: 635-640.

Saunders, J.W. 1977. The experimental analysis of chick limb bud development. In Vertebrate limb and somite morphogenesis, \{ed. D.A. Ede, J.R. Hinchliffe, and M. Balls), pp. 1-24. Cambridge University Press, Cambridge, England.

Saxén, L. 1987. Ontogenesis of the vertebrate excretory system. In Organogenesis of the kidney, (ed. P.W. Barlow, P.B. Green, and C.C. Wylie), pp. 1-34. Cambridge University Press, Cambridge, England.

Spector, D.L., R.A. Watt, and N.F. Sullivan. 1987. The v- and c-myc oncogene proteins colocalize in situ with small nuclear ribonucleoprotein particles. Oncogene 1: 5-12.

Sundin, O.H. and G. Eichele. 1990. A homeo domain protein reveals the metameric nature of the developing chick hindbrain. Genes \& Dev. 4: 1267-1276.

Thaller, C. and G. Eichele. 1990. Isolation of 3,4-didehydroretinoic acid, a novel morphogenetic signal in the chick wing bud. Nature 345: 815-819.

Tickle, C. 1980. The polarizing region and limb development. In Development in mammals (ed. M.H. Johnson), vol. 4, pp. 101-136. Elsevier/North-Holland Biomedical Press, Amsterdam, The Netherlands.

- 1991. Retinoic acid and chick limb bud development. Development 1 (Suppl.): 113-121.

van Straaten, H.W.M., F. Thors, E.L. Wiertz-Hoessels, J.W.M. Hekking, and J. Drukker. 1985a. Effect of a notochordal implant on the early morphogenesis of the neural tube and neuroblasts: Histometrical and histological results. Dev. Biol. 110: 247-254.

van Straaten, H.W.M., J.W.M. Hekking, F. Thors, E.L. WiertzHoessels, and J. Drukker. 1985b. Induction of an additional floor plate in the neural tube. Acta Morphol. Neerl.-Scand. 23: 91-97.

van Straaten, H.W.M., J.W.M. Hekking, E.L. Wiertz-Hoessels, F. Thors, and J. Drukker. 1988. Effect of the notochord on the differentiation of a floor plate area in the neural tube of the chick embryo. Anat. Embryol. 177: 317-324.

Wagner, M., C. Thaller, T. Jessell, and G. Eichele. 1990. Polarizing activity and retinoid synthesis in the floor plate of the neural tube. Nature 345: 819-822.

Wolpert, L. 1969. Positional information and the spatial pattern of cellular differentiation. $J$. Theor. Biol. 25: 1-47.

Woychik, R.P., T.A. Stewart, L.G. Davis, P. D'Eustachio, and P. Leder. 1985. An inherited limb deformity created by insertional mutagenesis in a transgenic mouse. Nature 318: 3640.

Woychik, R.P., R.L. Maas, R. Zeller, T.F. Vogt, and P. Leder. 
Trumpp et al.

1990a. "Formins": Proteins deduced from the alternative transcripts of the limb deformity gene. Nature 346: 850-853.

Woychik, R.P., W.M. Generoso, L.B. Russell, K.T. Cain, N.L.A. Cacheiro, S.J. Bultman, P.B. Selby, M.E. Dickinson, B.L.M. Hogan, and J.C. Rutledge. 1990b. Molecular and genetic characterisation of a radiation-induced structural rearrangement in mouse chromosome 2 causing mutations at the limb deformity and agouti loci. Proc. Nat1. Acad. Sci. 87: 2588-2592.

Yamada, T., U. Placzek, H. Tanaka, J. Dodd, and T. M. Jessell. 1991. Control of cell pattern in the developing nervous system: Polarizing activity of the floor plate and notochord. Cell 64: 635-647.

Zeller, R., K.D. Bloch, B.S. Williams, R.J. Arceci, and C.E. Seidman. 1987. Localized expression of the atrial natriuretic factor gene during cardiac embryo genesis. Genes \& Dev. 1: 693-698.

Zeller, R., L. Jackson-Grusby, and P. Leder. 1989. The limb deformity gene is required for apical ectodermal ridge differentiation and anteroposterior limb pattern formation. Genes \& Dev. 3: 1481-1492. 


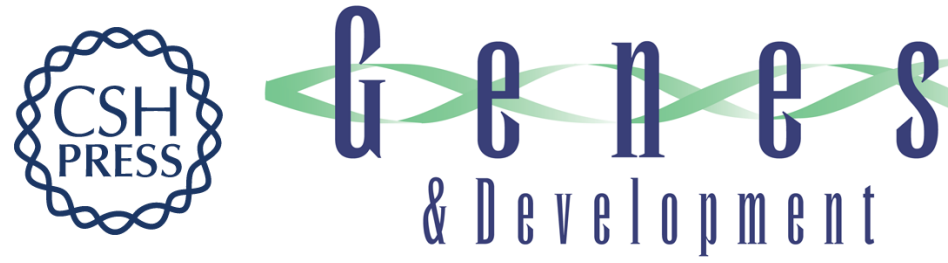

\section{The chicken limb deformity gene encodes nuclear proteins expressed in specific cell types during morphogenesis.}

A Trumpp, $P$ A Blundell, $J \mathrm{~L}$ de la Pompa, et al.

Genes Dev. 1992, 6:

Access the most recent version at doi:10.1101/gad.6.1.14

References This article cites 43 articles, 6 of which can be accessed free at:

http://genesdev.cshlp.org/content/6/1/14.full.html\#ref-list-1

License

Email Alerting

Service

Receive free email alerts when new articles cite this article - sign up in the box at the top right corner of the article or click here.

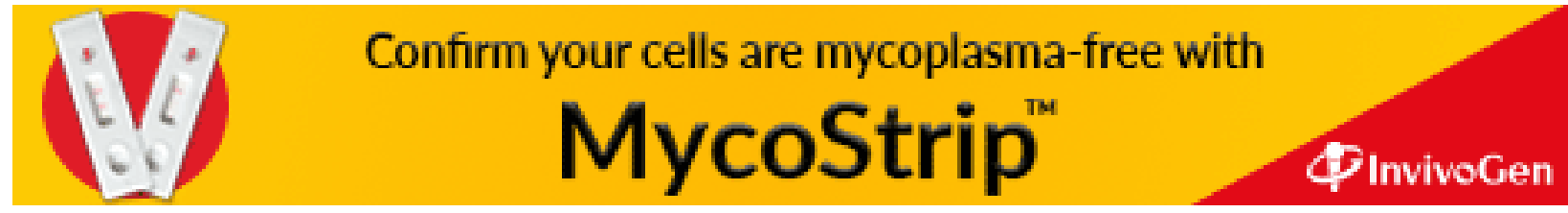

